\title{
Diet-Induced Changes in Serum Ganglioside Spectrum Patterns in 6-Month-Old Infants
}

\author{
Dida A. Gurnida, ${ }^{1}$ Ponpon Idjradinata, ${ }^{1}$ Deddy Muchtadi, ${ }^{2}$ Nanan Sekarwana, ${ }^{1}$ Bertram Fong, ${ }^{3}$ \\ Paul McJarrow, ${ }^{3}$ Angela Rowan, ${ }^{3}$ Carmen Norris ${ }^{3}$ \\ ${ }^{1}$ Department of Child Health, Faculty of Medicine, Universitas Padjadjaran, \\ Dr. Hasan Sadikin General Hospital, Bandung, Indonesia \\ ${ }^{2}$ Department of Food Science and Technology, Bogor Agricultural University, \\ Bogor, Indonesia \\ ${ }^{3}$ Fonterra Research Centre, Palmerston North, New Zealand
}

\begin{abstract}
Human milk contains higher levels of gangliosides when compared to infant formula. Gangliosides play a role in neuronal growth, migration, maturation, sinaptogenesis, and myelination. Seven of the identified gangliosides (GM1, GM2, GM3, GD3, GD1a, GD1b, and GT1b) are dominant gangliosides with different specific functions. Thus, the aim of the study was to understand the effects of ganglioside-enhanced diet and to compare the spectrum patterns of those seven classes of serum gangliosides in infants consuming standard infant formula (IF group), ganglioside-fortified infant formula (GA group) and exclusive breastfeeding (BF group). This study used liquid chromatography-mass spectrometry (LC-MS) method. This was a prospective study involving 30 infants in IF group, 29 in GA group and 32 in BF group. Subject recruitment was performed using consecutive admission approach from March 2008 to February 2009 in Bandung. Statistical analyses using Wilcoxon test showed that there was a significant change in the spectrum patterns of GD3, GM1, GM2 and GT1b in IF group; of GD1a, GM1 and GM2 in GA group and of GD1a, GD1b, GM1 and GM3 in BF group. It is concluded that ganglioside-enriched diet extends spectrum patterns of gangliosides especially in seven of them, i.e. GM1, GM2, GM3, GD3, GD1a, GD1b, and GT1b, in 6-month old infants. [MKB. 2012;44(4):240-44]..
\end{abstract}

Key words: Gangliosides, human milk, infants, infant formula, LC-MS

\section{Perubahan Pola Spektrum Gangliosida Serum yang Diinduksi Makanan pada Bayi Usia 6 Bulan}

\begin{abstract}
Abstrak
Air susu ibu (ASI) mengandung gangliosida yang kadarnya lebih tinggi dibandingkan dengan susu formula. Gangliosida berperan dalam pertumbuhan, migrasi, maturasi saraf, sinaptogenesis, dan mielinisasi. Tidak kurang dari 100 tipe gangliosida telah ditemukan, tujuh di antaranya (GM1, GM2, GM3, GD3, GD1a, GD1b, dan GT1b) merupakan kelas utama dengan fungsi yang berbeda. Penelitian ini bertujuan untuk mengetahui efek penambahan diet gangliosida serta membandingkan pola spektrum tujuh kelas gangliosida serum tersebut pada bayi yang mengonsumsi susu formula standar (kelompok infant formula/IF), susu formula difortifikasi gangliosida (kelompok GA), dan ASI eksklusif (kelompok breastfeeding/BF). Penelitian ini menggunakan metode liquid chromatography-mass spectrometry (LC-MS) untuk menghitung kadar ketujuh kelas gangliosida tersebut. Penelitian ini adalah penelitian prospektif yang melibatkan 30 bayi kelompok IF, 29 bayi kelompok GA, dan 32 bayi kelompok BF. Perekrutan subjek penelitian dilakukan dengan cara consecutive admission dari bulan Maret 2008 sampai bulan Februari 2009 di Bandung. Analisis statistik tes Wilcoxon menunjukkan perubahan bermakna pada pola spektrum GD3, GM1, GM2 dan GT1b pada kelompok IF; GD1a, GM1, dan GM2 pada kelompok GA; GD1a, GD1b, GM1, dan GM3 pada kelompok BF. Kesimpulan, penambahan diet gangliosida akan meningkatkan 7 spektrum gangliosida yaitu GM1, GM2, GM3, GD3, GD1a, GD1b, dan GT1b pada anak usia 6 bulan. [MKB. 2012;44(4):240-44].
\end{abstract}

Kata kunci: ASI, bayi, gangliosida, LC-MS, susu formula

Correspondence: Dida A. Gurnida, Departement of Child Health Faculty of Medicine Universitas Padjadjaran-Dr. Hasan Sadikin General Hospital, Pasteur 38 Bandung, mobile (022) 70122377, e-mail didaag@yahoo.com 


\section{Introduction}

Gangliosides, a large family of complex lipids that are abundant in the brain, have been shown to affect neuronal plasticity during development, adulthood, and aging and are considered to be possible therapeutics. ${ }^{1}$ Gangliosides in human milk and infant milk formula are considered as one of the bioactive components in human infant nutrition and have an important role during early infancy by modifying the intestinal microflora and promoting the development of intestinal immunity in neonates. ${ }^{2}$

Dietary gangliosides will produce increased ganglioside levels in the blood, as well as in other organs including the brain. ${ }^{3}$ Gangliosides are metabolized further via several routes, one of which involves direct glycosylation in the Golgi apparatus. This metabolism results in different classes of gangliosides (GM1, GM2, GM3, GD3, GD1a, GD1b, and GT1b) that have their own specific functions. ${ }^{3}$

The aim of this study was to compare the spectrum patterns of serum gangliosides due to different functions of each ganglioside class in infants who had consumed breastmilk, standard infant formula or ganglioside-fortified infant formula. The study has received approval from the Ethics Committee of Faculty of Medicine, Universitas Padjadjaran, Dr. Hasan Sadikin General Hospital Bandung. Written informed consent from parents was also obtained.

\section{Methods}

An analytic prospective study was conducted in a number of public health centers in Bandung. Subjects were selected based on consecutive admission sampling method. All subjects were healthy term infants, singleton births, with a birth weight of $\geq 2,500 \mathrm{~g}$ and no perinatal complications.

Ninety one healthy term infants, 2 to 8 weeks old, were recruited. Subjects of the study were divided into three groups: a group of infants consuming standard infant formula (IF group, 30 infants), a group of infants consuming ganglioside-fortified infant formula (GA group, 29 infants) and a group of exclusively-breastfed infants (BF group, 32 infants). The volume of breastmilk and formula consumed was quantified regularly.

In this study, we used liquid chromatographymass spectrometry (LC-MS) methods to measure the ganglioside composition in the serum. LC-MS offers improved sensitivity and selectivity over the more traditional thin layer chromatography (TLC) and high performance liquid chromatography (HPLC) methods for ganglioside detection. Five $\mathrm{mL}$ of blood was obtained from the sample and serum, which were then analyzed at the Fonterra Research Centre, Palmerson North, New Zealand. ${ }^{4}$

Briefly, the blood lipids were extracted using a Svennerholm and Fredman extraction protocol.3 The HPLC analysis was performed on an Agilent APS-2 Hypersil hydrophilic column $(150 \mathrm{~mm}$ x $2.1 \mathrm{~mm}, 3 \mu \mathrm{m}$, Thermo Electron Corporation, Waltham, MA) coupled to an APS-2 guard column (10 $\mathrm{mm} \times 2.1 \mathrm{~mm}$ inner diameter). The gangliosides were separated with an acetonitrile: ammonium acetate buffer gradient. The eluate from the HPLC system was introduced into an LTQ-Orbitrap ${ }^{\mathrm{TM}}$ mass spectrometer using an ESI probe inlet. MS data acquisition was carried out using the LTQ-Orbitrap ${ }^{\mathrm{TM}}$ mass spectrometer scanning in negative ion mode with a resolution of 30.000 over $700-1.650 \mathrm{~m} / \mathrm{z}$. The system was calibrated with ganglioside standards obtained from Matreya, LLC. The resolving power of the LTQ-Orbitrap ${ }^{\text {TM }}$ mass spectrometer was used for post analysis filtering for known masses of ganglioside species present within each class of ganglioside measured.

The spectrum patterns of serum gangliosides were quantified at baseline and again at 6 months, using LC-MS as described in Fong et al. ${ }^{4}$ Data were analyzed with Wilcoxon test, using SPSS version 17.0.

\section{Results}

At the beginning of the trial, 91 infants met the inclusion criteria of the study and were split into three groups: a group of infants consuming standard infant formula (IF group, 35 infants), a group of infants consuming ganglioside-fortified infant formula (GA group, 35 infants), and a group of infants receiving exclusive breastfeeding (BF group, 40 infants). The characteristics of these infants were presented in Table.

During the trial period (up to six months old) 19 infants dropped out: 5 from IF group, 6 from GA group and 8 infants from BF group. Data collection was performed twice a week by field assistants. The data consisted of frequency and duration of breastfeeding, fortified infant formula and standard infant formula consumption. using a structured questionnaire (Figure 1).

Using LC-MS as described in Fong et al., ${ }^{4}$ the subject's serum ganglioside spectrum patterns were quantified at baseline and again at 6 months (Figure 1)

There was a change from baseline to 6 months in the spectrum patterns of GD3 ( $p=0.035)$; GM1 $(p<0.001) ;$ GM2 $(p<0.001) ;$ GT1b $(p=0.005)$. 
Dida A. Gurnida: Diet-Induced Changes in Spectrum Patterns of Serum Gangliosides in 6-Month-Old Infants

Table Baseline Characteristics of Infants

\begin{tabular}{lccc}
\hline Characteritics & $\begin{array}{c}\text { Standard Infant } \\
\text { Formula/IF Group } \\
(\mathbf{n = 3 0 )}\end{array}$ & $\begin{array}{c}\text { Ganglioside-fortified } \\
\text { Infant Formula/GA } \\
\text { Group } \\
(\mathbf{n}=\mathbf{2 9})\end{array}$ & $\begin{array}{c}\text { Exclusively-breastfed } \\
\text { Infant/BF Group } \\
(\mathbf{n}=\mathbf{3 2})\end{array}$ \\
\hline Sex & & & \\
$\quad$ Male & 18 & 15 & 18 \\
$\quad$ Female & 12 & 14 & 14 \\
Birth weight (kg) & & & \\
$\quad$ Male & $3.21(2.50-3.90)$ & $3.18(2,60-3.80)$ & $3.13(2.60-3.80)$ \\
Female & $3.04(2.60-3.60)$ & $2.99(2.50-3.70)$ & $3.09(2.60-3.85)$ \\
Age (weeks) & $4.37(2-8)$ & $4.26(2-8)$ & $2.10(2-4)$ \\
\hline
\end{tabular}

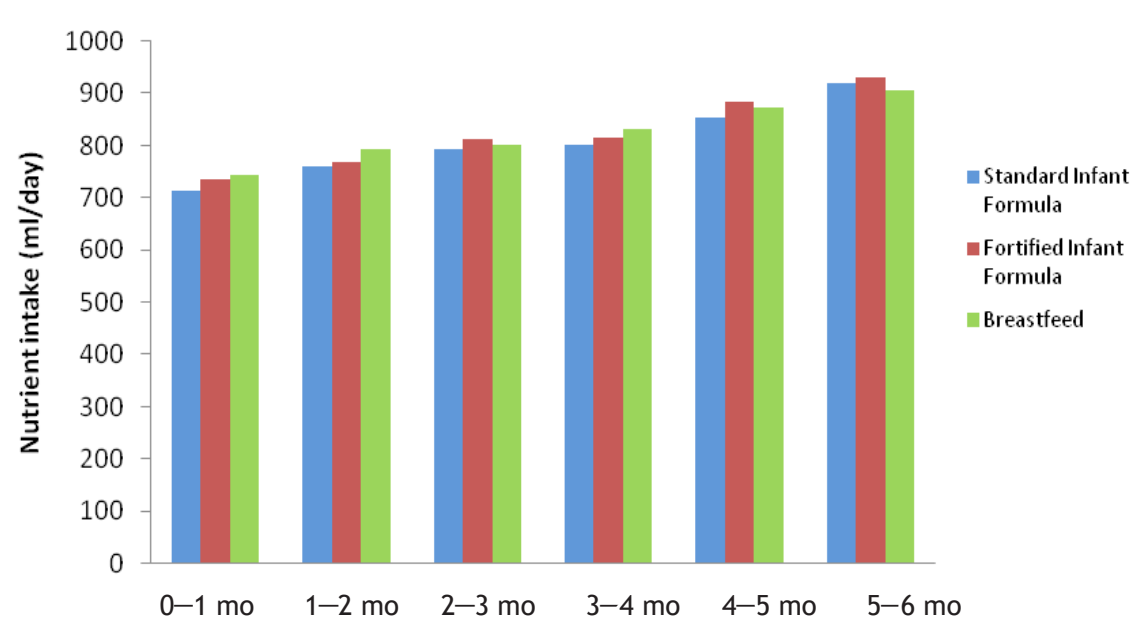

Age

Figure 1 Total Volume Breastmilk and Formula Intake

Note: per $100 \mathrm{~mL}$ fortified infant formula $=1.71 \mathrm{mg}$ gangliosides per $100 \mathrm{~mL}$ standard formula $=0.54$ mg gangliosides

In GA group, a change in the spectrum patterns occurs in GD1a ( $\mathrm{p}=0.005)$; GM1 ( $<<0.001)$; GM2 $(p<0.001)$. In $\mathrm{BF}$ group, there was a change in the spectrum patterns of GDla ( $\mathrm{p}=0.003)$, GD1b $(\mathrm{p}=0.033)$, GM1 $(\mathrm{p}<0.001)$, and GM3 $(\mathrm{p}<0.001)$

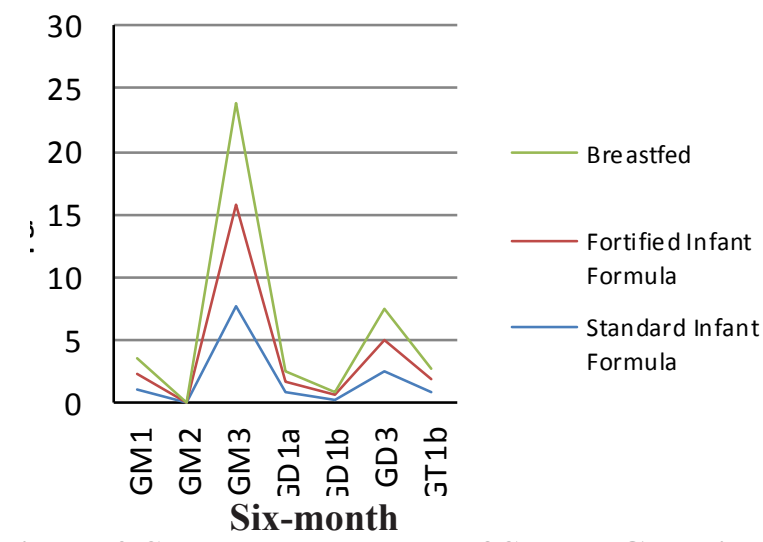

(Figure 2).

\section{Discussion}

Gangliosides are important substances in

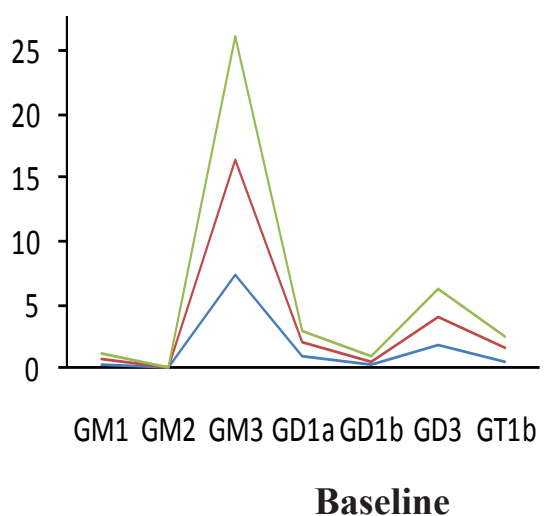

Figure 2 Spectrum Patterns of Serum Gangliosides at Baseline and at 6 Months 


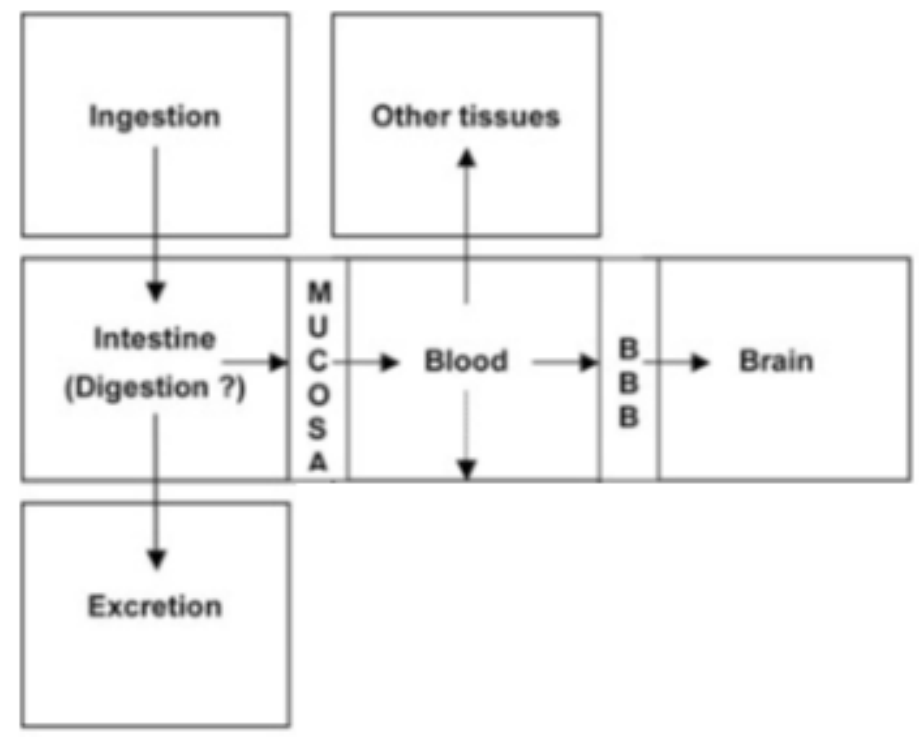

Figure 3 Uptake of Dietary Gangliosides by the Body ${ }^{3}$

cells and play some biological functions. There are at least 100 types of ganglioside structures which have been found in the last 20 years, and GM, GD and GT classes are dominant in brain, making up approximately $80-90 \%$ of the total mass of gangliosides. ${ }^{5}$ Gangliosides are also found in daily food such as in mammalian milk, eggs and meat products like liver, but not in plant -based foods. ${ }^{3}$ Amazingly, human breastmilk is the richest source of gangliosides. ${ }^{6}$ High level of GD3 gangliosides is found in human breastmilk colostrum and also in developing tissues.

Cow milk is used as the main source for infant formula production since the ganglioside distribution in cow milk is similar to that in human breastmilk although the levels in cow milk is a much lower. It is possible to restore the levels of gangliosides in infant formula by using an enriched preparation of the complex milk lipids from the milk fat globule membrane which has a higher proportion of gangliosides. Addition of this milk lipid ingredient into the infant formula formulation raises ganglioside levels to more closely match the levels reported for human breastmilk. Gangliosides injected into experimental animals would appear in the forms of misel, monometer and oligomer before they are absorbed by cells in solution. ${ }^{7}$ Serum Gangliosides are considered to appear in a form of one of those three.

Dietary gangliosides would arrive in digestive system in the same forms after coming through acid condition along the infant's gut. Dietary gangliosides are absorbed by small intestines and transported to different receptor membranes in the body. ${ }^{8}$ After absorbed by small intestines, dietary gangliosides may be reformed in the enterocyte, which will induce a change in the spectrum patterns of gangliosides in membranes. These gangliosides then come into blood circulation and finally cross the blood-brain barrier (BBB) (Figure 3).

In this study, a change in the spectrum patterns of some ganglioside classes in all groups was found at baseline and 6 months old (Figure 2). As mentioned above, each class of gangliosides has different functions. Concerning endogenous gangliosides, neuronal GD1a and GT1b were found to function as ligands for myelin-associated glycoprotein, promoting myelin stability and controlling nerve regeneration.8Another specific function of ganglioside GT1b in neurons that has been identified was $\mathrm{p} 58$, a brain-specific, sodiumdependent inorganic phosphate contrasporter and a GT1b-binding protein. ${ }^{10}$ In cell cultures of primary neurons and neuroblastoma cells, GM1 was discovered to be upregulated in the nuclear membrane following $\mathrm{Ca} 2+$-elevating stimulation and facilitates the efflux of nuclear $\mathrm{Ca} 2+.{ }^{12}$ Referring to data from genetic diseases, Tay-Sachs disease and related neuronal storage disorders-ganglioside GM2 is strongly suggested to be specifically involved in pyramidal neuron dendritogenesis ${ }^{11}$ although the mechanisms are still unknown. Likewise, a specific functional involvement of O-acetylated GD3 and GD2 in 
neuronal migration in the mammalian brain is most likely. However, the mechanisms are not yet clarified in this case. ${ }^{12}$

In conclusion, ganglioside-enhanced diet extends ganglioside spectrum patterns especially in seven of them, i.e. GM1, GM2, GM3, GD3, GD1a, GD1b, and GT1b in 6-months old infants.

\section{References}

1. Saito M, Mao RF, Wang R, Vadasz C, Saito $M$. Effects of gangliosides on ethanol-induced neurodegeneration in the developing mouse brain. Alcohol Clin Exp Res. 2007;31(4):66574.

2. Wang B, McVeagh P, Petocz P, Brand-Miller $\mathrm{J}$. Brain ganglioside and glycoprotein sialic acid in breast fed compared with formula-fed infants. Am J Clin Nutr. 2003;78(5):1024-9.

3. McJarrow P, Schnell N, Jumpsen J, Clandinin $\mathrm{T}$. Influence of dietary gangliosides on neonatal brain development. Nutr Rev. 2009;67(8):451-63.

4. Fong B, Norris C, Lowe E, McJarrow P. Liquid chromatography-high-resolution mass spectrometry for quantitative analysis of gangliosides. Lipids. 2009;44(9):867-74.

5. Wang B, Brand-Miller J. The role and potential of sialic acid in human nutrition. Eur J Clin
Nutr. 2003;57(11):1351-69.

6. Nakano T, Sugawara M, Kawakami H. Sialic acid in human milk: composition and functions. Acta Pediatr Taiwan. 2001;42(1):11-7.

7. Mobius W, Herzog V, Sandhoff K, Schwarzmann G. Gangliosides are transported from the plasma membrane to intralysosomal membranes as revealed by immuno-electron microscopy. Biosci Rep. 1999;19(4):307-16.

8. Park EJ, Suh M, Ramanujam K, Steiner K, Begg D, Clandinin MT. Diet-induced changes in membrane gangliosides in rat intestinal mucosa, plasma and brain. J Pediatr Gastroenterol Nutr. 2005;40(4):487-95.

9. Vyas AA, Schnaar RL. Brain gangliosides: functional ligands for myelin stability and control of nerve regeneration. Biochimie. 2001;83(7):677-82.

10. Ledeen RW, Wu G, Lu ZH, KozireskiChuback D, Fang Y. The role of GM1 and other gangliosides in neuronal differentiation. Overview and new finding. Ann N Y Acad Sci. 1998;845:161-75.

11. Walkley SU, Siegel DA, Dobrenis K, Zervas M. GM2 gangliosides as a regulator of pyramidal neuron dendritogenesis. Ann N Y Acad Sci. 1998;845:188-99.

12. Mendez-Otero R, Santiago MF. Functional role of glycolipid in directional movements of neurons. An Acad Bras Cienc. 2001;73(2):221-9. 